\title{
ABOUTTHE AUTHORS
}

Matthew W. Finkin holds a chair at the University of Illinois College of Law and an appointment at the University's Center for Advanced Study. He is the author of numerous books and articles and directs the College of Law's Program on Comparative Labor and Employment Law and Policy. Since 1997, he has co-edited the Comparative Labor Law and Policy Journal with Professor Sanford Jacoby of the Anderson Graduate School of Management at UCLA. Professor Finkin is a member of editorial boards of scholarly journals in the United States, Canada, Belgium, and Germany. He is a recipient of the Alexander von Humboldt Foundation's Research Prize and is a holder of honorary doctorates from the University of Trier (Germany) and the University of Athens (Greece).

Joel Cutcher-Gershenfeld is a professor and former Dean in the School of Labor and Employment Relations at the University of Illinois, United States. He is an awardwinning author who has co-authored or co-edited eight books and over eighty-five articles on high performance work systems, transformation in labor-management relations, negotiations and conflict resolution, economic development, and engineering systems. Joel is the former president of the Labor and Employment Relations Association (LERA). His current research centers on stakeholder alignment in complex systems - the foundation for 21st century institutions. Joel holds a Ph.D. in Industrial Relations from MIT and a B.S. in Industrial and Labor Relations from Cornell University. Joel is also affiliated with the National Center for Super Computing Applications (NCSA) and the University of Sydney, Australia.

Takashi Araki is Professor of Law at University of Tokyo and former Dean of its Law School. He is an award-winning author of two comparative books on German, U.S. and Japanese labor and employment law. In Japan, he is currently a member of the subcommittee, Labor Policy Council in the Ministry of Health, Labor and Welfare, and former chairperson of the Labor Relations Commission in the Tokyo Metropolitan government. Internationally, he is the former vice-president of the International Society for Labor and Social Security Law and actively involved in comparative studies in labor law and industrial relations. He has been a visiting scholar and professor at several institutions worldwide, including Harvard Law School, the Catholic University of Leuven, Cambridge University and the University of Illinois College of Law.

Philipp Fischinger is Akademischer Rat auf Zeit at the University of Regensburg, Germany and is currently writing his "habilitation" (postdoctoral lecture qualification) in order to become a professor of civil, employment and labor as well as social security law in Germany. He has published three books and numerous articles, on issues including civil liability, strike law, bankruptcy law and family law. He holds a doctoral 
degree from the University of Regensburg and an LL.M. degree from the Harvard Law School. He was a visiting professor at the University of Illinois College of Law in 2012.

Roberto Fragale Filho holds a doctorate in political science from the University of Montpellier I (1997) and teaches sociology of law at the Universidade Federal Fluminense (UFF). He has been visiting professor at the University of Illinois College of Law (2006) and the University Paul Valéry-Montpellier III (2009 and 2010). Since 2004, he has been the Labor Judge of the First Labor Section of the city of São João de Meriti (RJ), and has been the educational coordinator of the School of Magistrates of Rio de Janeiro Labor Court since 2009. During 2010, he was also Chairman of the National Council of Labor Schools of Magistrates (CONEMATRA). He is a member of the Comparative Labor Law and Policy Journal Editorial Advisory Board and has authored four books and over fifty articles in labor relations, judicial training, researching and teaching of law. His current research centers on judicial training and the impact of technology on the judicial profession.

Andrew Stewart is the John Bray Professor of Law at the University of Adelaide, Australia, and President of the Australian Labour Law Association. The author of many books and articles on Australian labour law, his current research projects include examining the regulation of unpaid work experience, analyzing the extent to which the protective strength of labour laws varies across countries with different legal systems, and preparing a comparative study of the regulation of job loss. Besides his academic work, he helps advise employers and business groups through his position as a consultant to law firm Piper Alderman.

Bernd Waas is Professor of Law at Goethe University of Frankfurt, Germany. He is the author or co-author of several books on individual as well as collective labor law and has written more than 100 articles on German, European and comparative labor and civil law. Bernd is coordinator of the European Labor Law Network which comprises labor law experts from 31 jurisdictions in Europe (ranging from Portugal to Russia). 